\title{
Den etiske dimension i undervisning - Om et grundtema hos Emmanuel Lévinas
}

\author{
Jonas Holst
}

I anledning af 50-året for udgivelsen af et af de mest betydningsfulde vorker $i$ det 20. århundredes filosofi, Emmanuel Lévinas' Totalitet og uendelighed, behandler artiklen et grundtema i vorket, nemlig forholdet mellem etik og undervisning. Det sker under inddragelse af den poedagogiske model, som

Jonas Holst, Det åbne Universitet i Zaragoza, filoholst@hotmail.com Lévinas anser for at stå i et modsatningsforhold til sin egen etiske forståelse af undervisning, den sokratiske maieutik. Den udførlige behandling af de to "positioner» skal imidlertid vise, at de har mere til folles, end det kommer frem i den første modstilling, hvilket giver mulighed for at formulere en mellemposition, der fastholder det etiske ved begge, og som er mere praktisk anvendelig $i$ undervisning end nogen af dem taget hver for sig.

Nøgleord: etik, undervisning, Lévinas, åbenbaring, Sokrates, maieutik, dialog

\section{English summary: The Ethical Dimension of Teaching - Based on a Main Theme in the Work of Emmanuel Lévinas}

On the occasion of the 50th anniversary of one of the most important works in 20th century philosophy, Emmanuel Lévinas' Totality and Infinity, the article presents a main theme of this work, the relationship between ethics and teaching. The discussion draws on another pedagogical understanding, which Lévinas considers to be opposed to his own ethical understanding of teaching, Socratic maieutics. A thoroughoing interpretation of the two "positions" shows, however, that they have more in common than what the opposition seems to elucidate at first. The sublation of the two will make it possible to sketch out a third ethical point of view, more applicable to teaching in practice than either of the two taken on its own.

Keywords: ethics, teaching, Lévinas, revelation, Socrates, maieutics, dialogue 


\section{Indledende bemærkninger}

Det er i år 50 år siden, at den fransk-jødiske tænker Emmanuel Lévinas, som oprindeligt var fra Litauen, udgav sit første, store hovedværk, Totalitet og uendelighed. Værket anses i dag for at være et af de mest betydningsfulde værker i det 20. århundredes filosofi, som Lévinas i høj grad var med til at sætte sit præg på og redefinere, særligt hvad der skal forstås ved etik. Med udgangspunkt i termer som ansigt, ansvar og goestfrihed forsøger Lévinas at tænke etik ud fra den andens side, ja, man kunne sige ud fra en anden side, end det hidtil er blevet gjort i den vestlige filosofis tradition, som primært har taget udgangspunkt $i$ et egenmægtigt subjekt, der skal være i stand til at styre sig selv og underlægge sig moralsk gyldige normer for at handle etisk.

Ifølge Lévinas får mennesket imidlertid ikke adgang til etikkens sfære alene i kraft af sin egen suverænitet, den være sig opretholdt af fornuftens love eller af normative regler. Tværtimod åbnes denne adgang, som Lévinas også kalder kongevejen til etikken, igennem modtagelsen af den anden, som underviser den, der modtager. Dette grundtema i Totalitet og uendelighed vil jeg udfolde i det følgende, idet jeg kontrasterer Lévinas' etiske forståelse af undervisning med en anden pædagogisk grundmodel, den sokratiske maieutik. Sigtet med denne dobbelte udlægningsstrategi er at præsentere en tredje etisk undervisningsform, der udligner forskellene mellem de to «positioner» og forsøger at fastholde det etiske og praktisk anvendelige ved dem begge.

\section{Åbenbaring versus maieutik}

Lévinas kommer allerede tidligt i Totalitet og uendelighed ind på den afgørende forskel, der består imellem hans egen tilgang til det etiske forhold og den måde, hvorpå Platon i sine dialoger beskriver den sokratiske tilgang: For Sokrates handler det i samtalen med andre om at vække erindringen om dyden i hver enkelt sjæl for at anvise en vej ind i det gode liv. Sokrates kalder i Platons dialog Theaitetos denne tilgang til sjælens generindring for jordmoderkunst, eller på oldgræsk maieutik, der består i at presse på, for at dialogpartneren bliver i stand til at nedkomme med det, som denne går svanger med (Platon 2001e: 148 E ff., 184 B; Platon 2001b: 82 A). Med Lévinas' ord bibringer den sokratiske maieutik ikke sjælen andet, end hvad den allerede selv ligger inde med, hvilket vil sige, at Sokrates i en vis forstand slet ikke underviser, men blot vækker mindet om noget glemt eller fortrængt i sjælen selv. Maieutikken forbliver med andre ord ifølge Lévinas inden for det sammes element, som ikke på noget tidspunkt brydes af det radikalt andet, der kommer udefra og skænker sjælen mere, end den i forvejen indeholder (Lévinas 1996: 34, 42). 
Det sidste begrebspar, det samme og det andet, former det grundlæggende modsætningsforhold i Totalitet og uendelighed. Hvad der umiddelbart kan forekomme at være et abstrakt modsætningspar, får dog straks et konkret indhold i forholdet mellem jeget og den anden: Lévinas beskriver jeget som en selvtilstrækkelig økonomi, der gør alt fremmed til det samme som sig selv; en tilegnelsesproces, der tager udgangspunkt i boligen forstået som ejendommens fortrolige sfære, hvor jeget hører hjemme og nyder sin tilværelse uden for alvor at blive udfordret. Jeget forbliver i sit eget element, som er det samme, så længe husets lukkede interiør består ubrudt. Et brud på jegets selvtilstrækkelige økonomi sker først i det øjeblik, hvor den anden kommer til og slår døren til jeg-huset ind ved at udtrykke sig til dets beboer (Lévinas 1996: 27-30, 167 ff.). Lévinas siger, at den andens ansigt er det helt andet, der ved sin blotte nærhed kalder på at blive svaret. Ansigtet kalder i sin nøgenhed på et ansvar, som jeget bydes at tage uden at kunne undslippe det. Selv når jeget vender sig bort uden at svare den anden, ja, selv når jeget svarer igen med vold, er det allerede mærket af den andens ansigt og vil forblive mærket deraf ligesom andre tilstedeværende om muligt vil have bemærket dets ansvarsløshed.

Vi møder i Totalitet og uendelighed en anden forståelse af samtale, ansvar og godhed end den, der kommer til udtryk i den sokratiske jordmoderkunst, som Lévinas med rette opfatter som en modsætning til sin egen. I modsætning til maieutikken sker der i Lévinas' etik en åbenbaring af den anden, som kommer med andet og mere, end jeget ligger inde med i forvejen, hvilket markerer en veritabel overskridelse af jeg-husets rammer, der dog samtidig udvides i modtagelsen af den anden. I forordet til Totalitet og uendelighed hedder det, at jeget kommer til at rumme noget, «som det hverken kan rumme eller modtage alene i kraft af sin egen identitet. Subjektiviteten realiserer denne umulige fordring: den overraskende kendsgerning at rumme mere, end det er muligt at rumme. Denne bog præsenterer subjektiviteten som modtagende den anden, som gæstfrihed» (Lévinas 1996: 17). Netop i kraft af at give den anden en gæstfri modtagelse kommer jeget til at rumme mere, end det selv indeholder, hvilket tager form af en undervisning, der giver dét at være ansvarlig for den anden en konkret mening, som jeget hverken på forhånd eller på egen hånd kan give sig selv.

Mens underviseren inden for en sokratisk inspireret pædagogik ikke anser sig selv for at overbringe sin elev andet end det, som denne selv potentielt indeholder, så er læremesteren i Lévinas' forståelse en overbringer eller selve åbenbaringen af noget, som den lærende er ude af stand til at give sig selv. I dét at undervise ligger der et moment af at vise noget, og umiddelbart ser det ud til, at maieutikken ikke viser eleven andet end det, som denne allerede selv indeholder. Til forskel herfra er den anden i åbenbaringsetikken læremesteren, som tiltaler jeget fra en højde, der hos Lévinas udlægges religiøst, hvilket gør undervisning til en åbenbaringsakt: Den lærende - 
som i et etisk og pædagogisk øjemed befinder sig under læreren - vises noget fra en højde, der uendeligt overskrider, hvad den lærende selv kan have indsigt i (Lévinas 1996: 92-96, 167).

Diskrepansen mellem de to «positioner» kan også illustreres ud fra det forskellige i undervisningssituationen: I de platoniske dialoger er Sokrates den ældre vismand, der ganske vist hævder ingenting at vide, men som dog har et godt øje til den andens sjæl. Sokrates beskrives af Platon som dialektikeren med en vis indsigt $i$ den andens sjæl, som han ansporer den anden til at tage vare på med alt det, som den rummer af godt (Platon 2001d: 270 D ff.; se også Platon 2001e: 150 B). Heroverfor lægger Lévinas vægt på det, som den anden kommer med, og som ikke på forhånd lader sig fastlægge endsige anskueliggøre. Den anden er den fremmede, som fra det eksteriøre giver jeget den etiske lærdom for, at det ikke vil kunne nærme sig vedkommende med en fastlåst og forudfattet forståelse, men alene ved at åbne sig og svare den anden forfra, ansigt til ansigt, parat «til at tage imod, til at give, til at have hænderne fulde, til gæstfrihed» (Lévinas 1996: 201). Det er ikke den anden, der skal svare for sig hos Lévinas, men jeget, som skal retfærdiggøre sig for at give ud af sin godhed som den gæstfrie og ansvarsfulde vært. Er denne undervisningssituation præget af andet- og fremmedhed, forekommer den sokratiske maieutik at fremelske en vis lighed med sagen selv og de samtalende sjæle imellem.

\section{Forberedelsen af en mellemposition}

Det skal ikke nægtes, at de to "positioner» - sådan som de i det foregående er blevet opstillet - udgør et modsætningspar, og at de ydermere bevæger sig på to forskellige argumentationsniveauer, som kan være vanskelige at forene med hinanden, hvilket jeg skal vende tilbage til lidt senere. Indtil videre ser det altså ikke ud til at være muligt at udligne forskellene mellem den sokratiske maieutik og den levinaske åbenbaringsetik, der virkelig synes at stå i et så skarpt modsætningsforhold til hinanden, som Lévinas understreger. ${ }^{1}$ Modsætningen er reel nok, men den er i det foregående blevet gjort skarpere, end den egentlig er, hvilket Lévinas ikke er uden skyld i.

I forhold til den maieutiske undervisningsform skal det siges, at den ikke er ude på helt at annullere sin egen indflydelse. Den er netop en hjælp, der står den anden bi med ledsagende råd og en filosofisk funderet omtanke, som kan lede på vej mod stadig større selverkendelse. At dømme ud fra de erkendelser, som Sokrates trods alt når frem til i de platoniske dialoger, har de ikke karakter af at være selvindlysende, men er snarere nogle «hårde fødsler», hvis egentlige sandhed måske aldrig når at komme helt frem i lyset. Platon skrev, ifølge eget udsagn, ikke et ord om de dybeste erkendelser og sandheder, hvorfor Sokrates i dialogerne ikke altid skubber på for at forløse det gode i det skønnes skin, men ofte holder noget tilbage, som han tilsyne- 
ladende forbliver tavs om. ${ }^{2}$ Samme sted, hvor Platon afviser at have lagt de højeste indsigter frem på skrift, bemærker han imidlertid, at de sjæle, der velvilligt har nærmet sig hinanden i den levende mundtlige samtale med hinanden, ligesom gnider de forskellige erkendelser mod hinanden for at frembringe den virkning, at indsigten i det højeste gode lyser op i sjælen som en gnist (Platon 2001d1: 341 D, 344 B).

Der kan næppe være tvivl om, at Platon i disse sætninger tænker på intentionen bag den sokratiske maieutik og dialogkunst, som altså ikke er nogen gnidningsfri erkendelsesteknik, der uden videre fremkalder ethvert indhold i den andens sjæl. De få steder, hvor Sokrates når frem til erkendelser med sin dialogpartner, bidrager han faktisk med andet og mere end en ren mekanisk bistand og bryder - i det mindste set ud fra dialogpartnerens synspunkt - med dennes forudfattede viden og selvforståelse uden at blive i det sammes element. Selvom det aldrig bliver til nogen fuldkommen erkendelse, består det etiske ved Sokrates' dialogiske undervisningsform - der som bekendt også rummer elementer af ironi og erotik - at den med tanke for den anden ledsager denne på vej imod at lære sig selv bedre at kende og dermed kunne tage bedre vare på sin egen sjæl, end denne givetvis på egen hånd ville have været i stand til. Med den moderne læringteoris begreber har Sokrates øje for elevens psykodynamiske ressourcer, der indbefatter tilegnelsesevne, interesse og motivation.

Lévinas kan stadigvæk have ret $\mathrm{i}$, at maieutikken forudsætter, at erkendelserne nærmest bare ligger og venter på at blive gravet frem; men vi har samtidig set, at det netop kræver et udgravningsarbejde, der ikke blot består i at «forløse en ånd, som allerede bærer på sin frugt (Lévinas 1996: 93)», som Lévinas så poetisk karikerer den sokratiske maieutik i Totalitet og uendelighed. Faktisk viser det sig, at Lévinas på det samme sted i dette værks forord, som vi tidligere citerede fra, indrømmer, at subjektiviteten, der modtager den andens undervisning, alligevel i en vis forstand rummer, hvad det ikke kan rumme alene i kraft af sig selv og sin egen identitet (Lévinas 1996: 17). Er det ikke også, hvad enhver undervisning må forudsætte for overhovedet at komme i gang, at den lærende besidder en vis evne til at lytte, forstå og i øvrigt gøre sig forståelig, hvilket samtidig vil sige en vis åbenhed over for læremesteren og det, som denne siger?

Lévinas ville sige, at denne åbenhed over for den anden sker med åbenbaringen af den anden, der gennembryder jegets «åndelige» ejendoms forsvarsværker og sætter spørgsmålstegn ved dets forudfattede viden. Og dog erkender han, at det sammes eller jegets «lukkethed heller ikke må gøre det umuligt at træde ud af interioriteten, således at eksterioriteten kan tale til det indre, åbenbare sig for det i en uforudsigelig bevægelse (Lévinas 1996: 145)», hvilket ikke er himmelvidt fra fremgangsmåden i den sokratiske dialog, der igennem bruddet med samtalepartnerens forudfattede viden åbner for en anden, videre forståelse. 
Efter at have «opblødt» det skarpe modsætningsforhold imellem de to «positioner» en smule skal vi på dette sted vende tilbage til det tidligere omtalte problem, at de hver især bevæger sig på to forskellige argumentationsniveauer. Mens den sokratiske maieutik og Platons filosofi i det hele taget omhandler den enkelte sjols vej imod stadig større selverkendelse, angår Lévinas' etik selve konstitutionen af hvert enkelt subjekt som sådan. Når Lévinas bruger begrebet undervisning, er det derfor i en noget anden betydning end den sokratiske og i det hele taget end den gængse. Den anden underviser ikke jeget i et bestemt sagsforhold eller tema, men bryder som nævnt med ethvert indhold, inklusive det, som jeget allerede ligger inde med. Den anden er den udefrakommende fremmede, som jeget først vil kunne rumme i den gæstfrie modtagelse, hvorfor Lévinas i begyndelsen af Totalitet og uendelighed siger, som vi tidligere citerede, at hans værk «præsenterer subjektiviteten som modtagende den anden, som gæstfrihed».

Når det alligevel giver mening at sammenholde og indtil en vis grad udligne forskellene imellem de to "positioner», skyldes det, at begge bygger på en etisk forståelse af undervisning og dialog som kritiske momenter i den gode sjæls konstitution. Modsætningsforholdet består stadigvæk imellem dem, men det skal vise sig, at den sokratiske dialogkunst ikke kan reduceres til maieutik. Den har andet og mere at byde på, hvilket Lévinas anerkender, når han uddyber den ekstraordinære måde, hvorpå den anden underviser: Han siger, at jegets modtagelse af den anden og undervisningen af jeget foregår i det diskursives mundtlige medium, som rummer et overskud, hvorigennem den talende kommer sin egen tale til hjoelp (Lévinas 1996: 62, 91-92). Det er alt sammen platoniske vendinger, og Lévinas undlader ikke at citere Platon gentagne gange med henblik på at skelne «det 'levende og sjælfyldte ord', som forstår i hvis selskab, den skal tale, og i hvis selskab, den gør vel i at tie» fra det skrevne ord uden sjæl, som ikke kan svare og komme sig selv til hjælp (Lévinas 1996: 66; se Platon 2001d: 275 E ff.). I Totalitet og uendelighed hedder det sågar, at denne hjælp, hvorigennem den anden vedvarende kommer til stede i sin tale, er selve sprogets essens, som udmønter sig i «gæstfrihed og venskab» (Lévinas 1996: 91, 306). ${ }^{3}$

Lévinas' eksplicitte brug af Platons dialogforståelse er et stort set overset tema i den 50-årige receptionshistorie af hans første hovedværk. Ofte har filosoffer et ambivalent forhold til deres store forgængere og åndsfæller, og Lévinas er altså ingen undtagelse. I første omgang lægger han afstand til den maieutiske fremgangsmåde, som vi imidlertid har set bidrager med andet og mere end det ene og samme. Maieutikken kommer ganske vist ikke med noget radikalt andet i den uendelige og transcendente forstand, som Lévinas forstår det. Alligevel gives samtalepartnerne i den sokratiske dialogform mulighed for at komme deres egen og om muligt hinandens tale til hjælp. Den dialogisk orienterede loeremester underviser altså ved at være til stede og svare på de spørgsmål, som den, der bliver undervist, måtte have, samtidig 
med at vedkommende har øje for dennes sjæl. Lévinas siger, at en sådan tale, der underviser ved at komme sine egne ord til hjælp, allerede rummer fortolkningsnøglen til sin egen forståelse (Lévinas 1996: 90). Det ligger igen tæt op ad en platonisk forståelse, som går ud fra, at den sag, der tales om og tematiseres i dialogen, forstået som en deling af logos, er nedlagt ude i midten mellem de samtalende (Platon 2001f: 14 B ff.). Ved at opholde sig ved logos - som på oldgræsk både betyder ord, tale og fornuft - og så at sige gnide erkendelserne imod hinanden vil de samtalende kunne få indsigt i sagen selv, der pludselig lyser op i sjælen (Platon 2001d1: $344 \mathrm{~B}$ ).

Derigennem skabes der en forbindelse fra sjæl til sjæl, som dog mere har karakter af en hændelse, hvilket er stærkt fremhævet i Platons brug af ordet pludselig. Lévinas synes ikke at være afvisende over for en sådan udlægning af den sokratisk-platoniske etik, men han ville særligt fremhæve den andens åbenbaring som den hændelse, hvorfra sjælen henter sin oplysning. I sammenhæng hermed henviser han ikke alene til Platon, men også til Aristoteles' analyser af det aktive intellekt, der kommer udefra og sætter den modtagende i stand til at tænke videre og ud over sine egne forudfattede meninger og tanker (Lévinas 1996: 42), hvilket er et sindbillede på selve dét at modtage ideen om uendelighed: et hus, der kan «rumme mere, end det er muligt rumme», og «en tanke, der hvert øjeblik tænker mere, end den tænker» (Lévinas 1996: 17, 40, 54).

Vi har opholdt os et stykke tid ved disse afgørende passager i Totalitet og uendelighed, da de stort set er forblevet upåtalte og uudforskede i Lévinasforskningen, som i højere grad har lagt vægt på hans filosofi som en forskelstænkning og kritik af den oldgræske logos-filosofi. Disse to aspekter af hans filosofi er med rette blevet fremhævet, da Lévinas distancerer sig fra den vestlige filosofi som egologi og lægger denne distance ind i forholdet mellem det samme og det andet, jeget og den anden, som han fastholder ikke er noget fait accompli, det vil sige et faktuelt, fuldbyrdet forhold. Ifølge Lévinas bevares afstanden mellem de samtalende netop i sproget, samtidig med at de bringes $i$ levende berøring med hinanden, og i den sammenhæng er det, at den platoniske dialogfilosofi kommer ham til hjælp.

Problemet med udelukkende at læse Lévinas som forskelstænker og kritiker af den oldgræske logos-filosofi består dog ikke alene i, at de her fremlæste ansatser i hans værk til konkret at udfolde en etisk og dialogisk orienteret forståelse af undervisning - oven i købet under inddragelse af den såkaldte oldgræske logos-filosofi - overses; men tillige i at en ren forskelstænkning, der bliver stående ved en uoverstigelig afstand mellem etikkens termer, får vanskeligt ved at forklare, hvordan disse kommer i berøring med hinanden og gør det på en etisk måde. ${ }^{4}$ Dermed vender vi tilbage til vores tema om den etiske dimension i undervisning, som vi har forsøgt at udfolde igennem fremstillingen af to modsatrettede tankegange, begge med en vis ekstrem tendens indbygget. Sokrates overdriver tydeligvis, når han hævder 
slet ikke at undervise, og at ethvert vidensindhold i sjælen ligger klar til at blive undfanget som et barn, der kommer færdigt til verden. I virkeligheden er enhver sjælelig erkendelse i en fortsat forandringsproces, i og med den formuleres, hvilket er grunden til, at den sokratiske dialogkunst faktisk kan siges at bidrage med andet og mere end det, som den pågældende dialogpartner allerede ved.

Til forskel fra den sokratiske yderlighed, der er tæt på at reducere alle sjæles erkendelse til det samme, tenderer Lévinas i Totalitet og uendelighed konsekvent imod at afsondre jeget så radikalt fra alt andet og uden andre etiske ressourcer end dem, der kommer udefra med den andens ankomst, at jeget helt er givet i hænderne på den anden og næppe kan siges at have noget som helst ansvar for egen læring. Hvad nu hvis den anden i egenskab af underviser og med sit nøgne ansigtsudtryk bryder ind hos og gør vold på jeget, vil jeget så stadigvæk i samme forstand kunne siges at være etisk ansvarlig for den anden og dennes forbrydelse? Der findes passager i Totalitet og uendelighed, hvor Lévinas omtaler den andens ansigt og indbrud i jeghuset som indiskret og voldeligt, hvilket føres ud i det ekstreme i hans andet hovedværk, Anderledes end væren, med hvis formuleringer den anden holder jeget som gidsel og kommer som en røver i natten, der efterlader jeget traumatiseret. Det er et spørgsmål, om det overhovedet lader sig gøre at tænke en etik og en etisk orienteret undervisning på dette grundlag ${ }^{5}$, hvilket stadigvæk er muligt i Totalitet og uendelighed; men som vi har lagt op til fra begyndelsen, vil det skulle ske i afbalanceringen af de to opstillede og tendentielt set ekstreme «positioner».

\section{Undervisningens etiske dimension}

Når der inden for moderne pædagogik tales om det, som vi har givet samlebetegnelsen undervisningens etiske dimension, sker det ofte ud fra den betragtning, at undervisning ikke kun skal bero på indlæring og videnspåfyldning, men at den tillige skal lægge op til dannelsesorienterede loringsprocesser, hvori eleven bliver medinddraget og gives mulighed for selvstændigt at reflektere over det faglige vidensindhold. ${ }^{6}$ Formuleringen af en tredje mellemposition på grundlag af den kritiske udlægning af den sokratiske maieutik og den levinaske åbenbaringsetik vil kunne yde et væsentligt bidrag til at gentænke det etiske ved et sådant oplæg i undervisningen.

Platons Sokrates er med sin tillid til den lærendes egne ressourcer den, der mest åbenlyst lægger op til selvstændig refleksion over et givet vidensindhold; men det er samtidig klart, at hvis ethvert menneske havde direkte adgang til alle de ressourcer, der ville sætte det i stand til selv at lære sig og forholde sig kritisk til et hvilket som helst indhold, så ville det i princippet gøre undervisning som sådan overflødig. Undervisning er der til, så længe 
mennesket har brug for ekstra kræfter, som Lévinas formulerer det (Lévinas 1996: 201), med henblik på at åbne sig for den visdom, der ligger hinsides dets egen horisont. Denne levinaske indsigt har Erling Lars Dale formuleret på den måde, at undervisning i sig selv er en ressource i det omfang, den forsyner eleven med forskellige fortolkningsmønstre og færdigheder, værdiskemaer og udtryksmåder (Dale 2000: 30), hvilket han angiver som selve «almendannelsens retningsbestemmelse», der er «en bevægelse ud over det, der er én selv, hen imod en absolut Anden. (Dale 2000: 77)». Undervisning bygger, ifølge Dale, på en modtagelse af den andens ansigt, dennes første ord og udtryk, som udgør «undervisningens livsnerve», og han konkluderer, at «således har rationaliteten i skoletilværelsen sin etiske forudsætning ... Jeg tror, fornuftens aktivitet begynder med et svar på den uendelighed, der trænger sig på uden vold i mødet med den Anden som lærer». (Dale 2000: 77)

Det er en træffende reformulering af Lévinas' etiske forståelse af undervisning. I det foregående har vi særlig opholdt os ved og uddybet det ikkevoldelige moment $i$ denne forstålse, nemlig lærerens tilstedeværelse i sin egen tale, som han eller hun uafladeligt kommer til hjælp og dermed også hjælper eleven med at nå ud over sin egen horisont, hvilket udgør de diskursive momenter, der er med til at forme den etiske dimension i undervisning. Det er samtidig på dette sted i den levinaske diskurs, at den sokratiske dialogkunst får en opbyggelig rolle at spille, hvilket i det følgende skal give os lejlighed til at formulere en tredje og mere praktisk anvendelig mellemposition: Er undervisning som en etisk ressource blevet gjort gældende over for den sokratiske maieutiks selvudslettende pædagogik, må det i forhold til Levinas' åbenbaringsetik fastholdes, at undervisning i et etisk øjemed ikke direkte forsyner eller indprenter eleven noget, men at denne bliver ledsaget af læreren igennem en kritisk refleksionsproces, der gør elevens egne ressourcer tilgængelige og anvendelige.

En ren maskinel overførsel af information, der på ingen tid sætter mennesket i stand til at lære noget - ligesom det sker i den moderne informationsalders kultfilm Matrix - kan ikke siges at være undervisning. Sokrates forholder sig et sted spøgefuldt til en sådan påfyldning af sjælen: «Det ville være fortræffeligt,» siger han, «hvis visdom var en sådan størrelse, som i det øjeblik, hvor vi nærmede os hinanden, flød fra det mere fyldte over i det tommere ligesom vand i bægere, der flyder gennem en uldtråd fra det mere fyldte over i det tommere» (Platon 2001c: 175 D). I en anden sammenhæng tager han dog realiteten af en sådan bevidstløs videnspåfyldning mere alvorligt, da der er nogle, der giver sig ud for at være vise - i Platons univers de såkaldte sofister - og som sælger ud af deres viden uden at tage højde for den lærendes sjælelige forfatning. For eleven kan det vise sig at blive et yderst dyrt bekendtskab, for når handlen først er indgået, er der ingen 
mulighed for at bytte den købte «vare», der går rent ind i sjælen (Platon 2001a: 313 D-314 B).

Hvad Platon især klandrer sofisterne for, er deres mangel på etik i omgangen med deres elever, hvilket er en indvending, hvis berettigelse om muligt kan diskuteres. Det gør os imidlertid opmærksom på det etiske aspekt, som vi ad flere gange har forsøgt at fremhæve ved den sokratiske dialogform, og som på sin side er med til at forme den etiske dimension i undervisning, nemlig at have øje for den lærendes sjæl. Det er et aspekt, som falder i baggrunden hos Lévinas, der til tider lægger så meget vægt på den højhed og religiøse ave, som underviseren indgyder, at han får vanskeligt ved at skelne sand undervisning fra indoktrinering. Til forsvar for Lévinas skal det siges, at den ide, der af den anden sættes i jeget, er ideen om uendelighed, som er selve det, der hverken kan begribes eller rummes, hvorfor jeget snarere end at tvinges gøres mere fri. Det uendelige sprænger, ifølge Lévinas, jegets egoisme, men dermed er det stadigvæk nødvendigt at sige noget mere, for en «uendelig» sprængning af jegets grænser udgør ikke i sig selv nogen etisk undervisningsform og gør ikke uden videre nogen mere fri. Netop dét at sige noget mere er imidlertid, hvad Lévinas i sit første hovedværk under inddragelse af Platon betoner vigtigheden af, hvilket består i uafladeligt at komme sin egen tale til hjoelp og «afsige» det allerede sagte, den umælende skrift, de stivnede høflighedsformer og i det hele taget enhver form for forudfattede og fordomsfulde meninger (Jf. Lévinas 1996: 20, 58).

Undervisning udgør i det etiske perspektiv, som vi igennem en udlignende formidling af de to "positioner» har forsøgt at anlægge, selv en ressource i elevens tilværelse og tager samtidig højde for elevens egne ressourcer. Den faglige indlæringsproces handler med Lévinas' ord om modtagelsen af noget, der overstiger elevens horisont, men som læreren samtidig er kaldet til - hvilket er Sokrates' synspunkt - at afstemme med den enkelte elevs anlæg, evner og erfaring, hvis undervisningen skal give plads til ansvarsbevidst læring og kritisk stillingtagen. Det sidste kan ikke overlades til eleven alene, men der må allerede ligge et incitament i lærerens undervisningsoplæg til kritisk refleksionsdannelse hos eleven. Både Lévinas og Sokrates anskuer selve undervisningsakten som et brud på elevens jegstrukturerede, eller om man vil, selvcentrerede forudforståelse. Men skal undervisningen ikke blot efterlade eleven alene tilbage med bruddet, men samtidig gøre vedkommende åben over for det, der ligger hinsides dennes egen horisont, må der i undervisningen følge en ledsagelse med, som hjælper eleven med at hente ressourcer frem, i det øjeblik hvor denne når ud til grænserne for sin egen forståelse. Denne hjælp, som er med til at forme undervisningens etiske dimension, har vi med Platon og Lévinas beskrevet som den talendes tilstedeværelse i sin egen tale ved uafladeligt at komme den til hjælp og dermed også assistere den lærende i samtalen under hen- 
syntagen til, hvor denne befinder sig henne menneskeligt, hvilket også vil sige sjæleligt.

Denne hjælp og ledsagelse finder for både Platon og Lévinas sted i samtalens mundtlige medium, der giver mulighed for lærer og elev til at indgå i en kritisk, dialogisk udveksling ansigt til ansigt omkring en fælles sag, samtidig med at hver elev vil kunne arbejde selvstændigt, hvilket næppe lader sig gøre $i$ et skriftligt endsige elektronisk medium. Bevægelsen fra den anden til det samme - for at tale med Lévinas' begreber - beskriver den måde, hvorpå loereren retter talen til eleven med ansigtet vendt hen imod denne og er til stede $i$ sin tale ved at fremlogge en fortolkningsnøgle til at forstå det sagte, hvilket markerer en oprigtighed fra lærerens side, som eleven vil kunne modtage og respondere på, lytte til og aktivt argumentere for eller imod. At tale til den anden så at sige fra siden, eller endnu værre at tale om den anden bag dennes ryg, svarer til at fordreje og gøre vold på selve samtale- og undervisningssituationen, i hvilken de involverede fra begyndelsen er sårbare. Undervisningen er i høj grad med til at konstituere den lærende som subjekt, hvilket viser sig ved de personlige kriser, som en elev kan komme ud for, når vedkommende ikke bliver integreret i undervisningen. Af den grund er det altafgørende for, at den etiske dimension forbliver synlig i undervisningen, at læreren henvender sig til eleven forfra med ansigtet vendt hen imod denne som et tegn til hvert øjeblik at kunne være til stede i sin tale ved at komme talen, og dermed også eleven, til hjælp. I den fremstillede mellemposition fuldbyrdes konstitutionen af det lærende subjekt imidlertid ikke som hos Lévinas i elevens ansvar for den anden, læremesteren, men derimod i den dannelsesorienterede læringsproces, hvorigennem eleven - ledsaget af læreren - begynder at tage ansvar for sig selv og sin egen livssituation.

For at samle op på denne afsluttende diskussion med afsæt i integrationen af de to behandlede "positioner» består den etiske dimension i undervisningen af en udvidelse af elevens ressourcer under hensyntagen til dennes egne ressourcer, hvilket forener henholdsvis det passivt modtagende moment, der er stærkt fremhævet hos Lévinas, og det aktivt agerende moment, som Sokrates understreger. Eleven befinder sig nok i en vis forstand under læreren, for så vidt der i selve dét at undervise ligger dét at vise noget, som overskrider elevens horisont, men den ansvarlige for undervisningen har tillige et etisk ansvar at leve op til, hvilket kun kan ske ved at tage udgangspunkt i og hensyn til eleven selv. Den mundtlige samtale er blevet fremstillet som det privilegerede medium, hvori der kan finde en udveksling sted, som giver læreren mulighed for at overskride og dermed bryde med sine elevers forudforståelse, samtidig med at han eller hun ledsager dem ved at udlægge en fortolkningsnøgle til det sagte, og hvor eleverne vil kunne lytte og udtrykke sig, opleve og gøre erfaringer med en kritisk og ansvarlig bevidsthed om, hvad der er med til at konstituere deres egen selvforståelse, og hvad der kan føre dem frem til stadig større selverkendelse. 


\section{Tak}

Jeg vil gerne rette en tak til de to anonyme «granskere», som med deres kommentarer har været med til at forbedre mit bidrag.

\section{Noter}

1 Strhan (2007) er en af de få, der har behandlet dette modsætningsforhold, men hun anskuer det alene ud fra Lévinas' synspunkt uden at forsøge at finde et fælles mødepunkt for de to "positioner». I et par slutnoter gør hun dog opmærksom på, at Lévinas' komplekse forhold til Platon samt de praktiske implikationer af hans begreb om undervisning kræver at blive undersøgt nærmere, hvilket er et arbejde, der vil blive påbegyndt i det følgende.

2 For en systematisk Platonudlægning, der forfølger Sokrates' tilbageholdelsesmanøvre i dialogerne, se Szlezák (1985), som samtidig viser, hvor væsentligt begrebet om at komme sin egen tale til hjælp er i de platoniske dialoger, men mere om det lidt senere.

3 Jeg har andetsteds uddybet det forhold, der består imellem gæstfrihed, undervisning og venskab i Totalitet og uendelighed, se Holst (2011).

4 Ligesom Strhan har Wirzba (1995) givet en længere fremstilling af modsætningsforholdet imellem sokratisk maieutik og Lévinas' position, som han betegner metanoia, hvilket henviser til den åbning og omvending af subjektiviteten ud imod det eksteriøre, der finder sted i det etiske undervisningsforhold. Han undlader dog ligesom Strhan at komme nærmere ind på det, som de to «positioner» har til fælles, hvilket ellers ville have været muligt med afsæt i det oldgræske begreb metanoia, som Platon ganske vist ikke bruger (se dog Euthydemos $279 \mathrm{C}$ for den verbale form af denne term), men hvis anagogiske betydning han tydeligvis kender til, hvilket fremgår af den berømte hulelignelse, hvor begrebet om omvending - også ifølge Lévinas - henviser til en transcendent dimension, nemlig det godes ide. Undervisning er dog hverken for Platon eller for Lévinas blot en øjenåbner ud imod en distant, transcendent ide, men indebærer konkret at komme sin tale til hjælp i en fortsat bevægelse, der rummer en fortolkningsnøgle til det sagte.

5 For en lignende kritisk stillingtagen til, om Anderledes end væren overhovedet kan siges at handle om etik og ansvar, eller om Lévinas i dette værk snarere er på grænsen til at umuliggøre disse begrebers anvendelse, se Kjerschow (1995), Ricoeur (1997) og Frandsen (2001): 163.

6 Jf. Strike (1998), Bartel (2002), Vestergaard (2003).

\section{Litteratur}

Bartel, U. (2002) Das Sokratische Gespräch in der Grundschule. Ethik und Unterricht 1, s. 17-20.

Dale, E.L. (2000) Etik og moral i uddannelsessystemet. Aarhus: Klim.

Frandsen, H.V. (2001) Emmanuel Lévinas og kærlighedens visdom. Odense: Odense Universitetsforlag. 
Holst, J. (2011) Hospitalidad como iniciación a la ética. Alea - Revista Internacional de Fenomenología y Hermenéutica 9, s. 59-74.

Kjerschow, P.C. (1995) Ansvarshavende som søvngjenger? I sporet af det uendelige. En debattbok om Emmanuel Levinas, red. Kolstad, Bjørnstad, Aarnes, s. 107114. Oslo: Aschehoug.

Lévinas, E. (1996) Totalitet og uendelighed. København: Hans Reitzels Forlag.

Platon (2001a) Protagoras - Band 1 Platon Werke. Darmstadt: WBG.

Platon (2001b) Menon, Euthydemos - Band 2 Platon Werke. Darmstadt: WBG.

Platon (2001c) Symposion - Band 3 Platon Werke. Darmstadt: WBG.

Platon (2001d) Phaidros - Band 5 Platon Werke. Darmstadt: WBG.

Platon (2001d1) Epistolai (Breve) - Band 5 Platon Werke. Darmstadt: WBG.

Platon (2001e) Theaitetos - Band 6 Platon Werke. Darmstadt: WBG.

Platon (2001f) Philebos - Band 7 Platon Werke. Darmstadt: WBG.

Ricoeur, P. (1997) Autrement. Paris: Presses Universitaires de France.

Strhan, A. (2007) 'Bringing Me More Than I Contain...': Discourse, Subjectivity and the Scene of Teaching in Totality and Infinity. Journal of Philosophy and Education, 41 (3), s. 411-430.

Strike, K.A. (1998) The Ethics of Teaching. New York: Teachers College.

Szlezák, T. (1985) Platon und die Schriftlichkeit der Philosophie. Berlin: Walter de Gruyter.

Vestergaard, E. (2003) Etik og loering. Vejle: Kroghs Forlag.

Wirzba, N. (1995) From maieutics to metanoia: Levinas' Understanding of the philosophical task. Man and World, 28, s. 129-144. 